CARDIOLOGY UPDATE

\title{
Antiplatelet therapy in cardiovascular disease
}

\author{
M W H Behan, R F Storey
}

Postgrad Med J 2004;80:155-164. doi: 10.1136/pgmi.2003.007062

Platelet activation and aggregation are considered to be central to arterial thrombus formation. Antiplatelet therapy is therefore important for both the treatment and prevention of cardiovascular disease. Aspirin, the most widely used antiplatelet agent, inhibits platelet cyclo-oxygenase and the conversion of arachidonic acid to the potent platelet agonist thromboxane $A_{2}$ but does not prevent platelet activation occurring via various signalling pathways that are independent of thromboxane $A_{2}$ release. Therefore a number of other compounds have been developed to complement aspirin's beneficial effect. These include the thienopyridines (clopidogrel and ticlopidine), dipyridamole, and the $\alpha_{\| \mathrm{lb}} \beta_{3}$ (glycoprotein $\mathrm{llb} / \mathrm{llla}$ ) receptor inhibitors.

See end of article for authors' affiliations ......................

Correspondence to: Dr M W H Behan, Clinical Research Fellow, Division of Cardiovascular Medicine, University Hospital, Derby Road, Nottingham NG7 $2 \mathrm{UH}$

UK; miles.behan@ nottingham.ac.uk

Submitted

27 February 2003

Accepted 8 June 2003
$\mathrm{T}$ he leading cause of morbidity and mortality in the Western world is cardiovascular disease. ${ }^{1}$ Thrombotic and thromboembolic occlusions of atherosclerotic blood vessels are the main cause of ischaemic events. ${ }^{23}$ Since the observation that thrombi occluding coronary arteries were platelet-rich in content, antiplatelet agents have been extensively researched and developed as potential therapies in the prevention and management of arterial thrombosis. ${ }^{4}$

Platelet activation and aggregation is considered to be central to arterial thrombus production. ${ }^{56}$ This review discusses currently available antiplatelet agents and their mechanisms of action (fig 1). There are four main groups: aspirin, the thienopyridines (ticlopidine and clopidogrel), dipyridamole, and the platelet $\alpha_{\mathrm{IIb}} \beta_{3}$ (glycoprotein IIb/IIIa) receptors antagonists.

Aspirin has been regarded as the prototype antiplatelet drug and is still the most widely used agent. It inhibits irreversibly the enzyme cyclooxygenase, thereby blocking conversion of arachidonic acid to endoperoxides such as thromboxane $\mathrm{A}_{2}$ in platelets and prostaglandin $\mathrm{I}_{2}$ in vascular endothelium. However, platelet activation occurs via several pathways that do not rely on amplification by released thromboxane $\mathrm{A}_{2}$. A number of other compounds have been developed to complement the therapeutic effect of aspirin.

\section{PATHOGENESIS OF THROMBOSIS}

The acute coronary syndromes form a spectrum of coronary disease from unstable angina to nonQ-wave and Q-wave myocardial infarction. ${ }^{7}$ They are caused by the development of thrombus on a ruptured coronary atherosclerotic plaque (fig 2). ${ }^{28}$ This plaque consists of a core of lipid and collagen covered by a layer of connective tissue. Also present in the core are cholesterolcontaining macrophages (foam cells), derived from monocytes that have crossed the endothelium from the arterial lumen. These cells produce large amounts of prothrombotic tissue factor together with several inflammatory cell mediators such as tumour necrosis factor- $\alpha$ and various interleukins. ${ }^{310}$

The process of thrombosis starts when the atherosclerotic plaque tears and exposes the lipid-rich core to blood in the arterial lumen. Platelet adherence to the exposed subendothelium and collagen results in platelet activation and the release and local accumulation of soluble platelet agonists (thrombin, adenosine diphosphate (ADP), serotonin, and thromboxane $A_{2}$ ). This in turn causes further platelet aggregation, coronary artery vasoconstriction, and subsequent reduction in coronary artery blood flow. ${ }^{11}$ On the surface of the activated platelet the integrin $\alpha_{\text {IIb }} \beta_{3}$ (glycoprotein IIb/IIIa) receptor undergoes a conformational change, allowing the platelets to bind fibrinogen tightly. Fibrinogen acts as a bivalent ligand and allows the formation of stable platelet aggregates through cross linking of $\alpha_{\mathrm{IIb}} \beta_{3}$ receptors. ${ }^{12}$ In this way $\alpha_{\mathrm{IIb}} \beta_{3}$ mediates the so-called "final common pathway" of platelet aggregation. It has to be remembered that platelets not only promote thrombosis but also impede fibrinolysis by the secretion of factors such as plasminogen activation inhibitor $1 . .^{13} 14$

Platelets are the "major player" in arterial thrombosis and therefore are attractive targets in the prevention and treatment of cardiovascular disease. Coronary thrombosis often precedes or complicates percutaneous coronary interventions (PCI), including percutaneous transluminal coronary angioplasty (PTCA) and intracoronary stent implantation, and refining antiplatelet therapy to cover these procedures, as well as to treat acute coronary syndromes, has been the objective of many clinical trials.

\section{ASPIRIN}

Bayer Co patented acetyl-salicylic acid in 1899 under the trade name of aspirin ("a" stood for acetyl and "spir" stood for spirasaure, the German word for salicylic acid). ${ }^{15}$ Aspirin was used initially as an analgesic and an antipyretic; however its effects on haemostasis were recognised as early as $1945 .{ }^{16}$ The antithrombotic

Abbreviations: ADP, adenosine diphosphate; CAMP, cyclic adenosine monophosphate CATP, cyclic adenosine triphosphate; cGMP, cyclic guanine monophosphate; $\mathrm{PCl}$, percutaneous coronary intervention; PTCA, percutaneous transluminal coronary angioplasty 


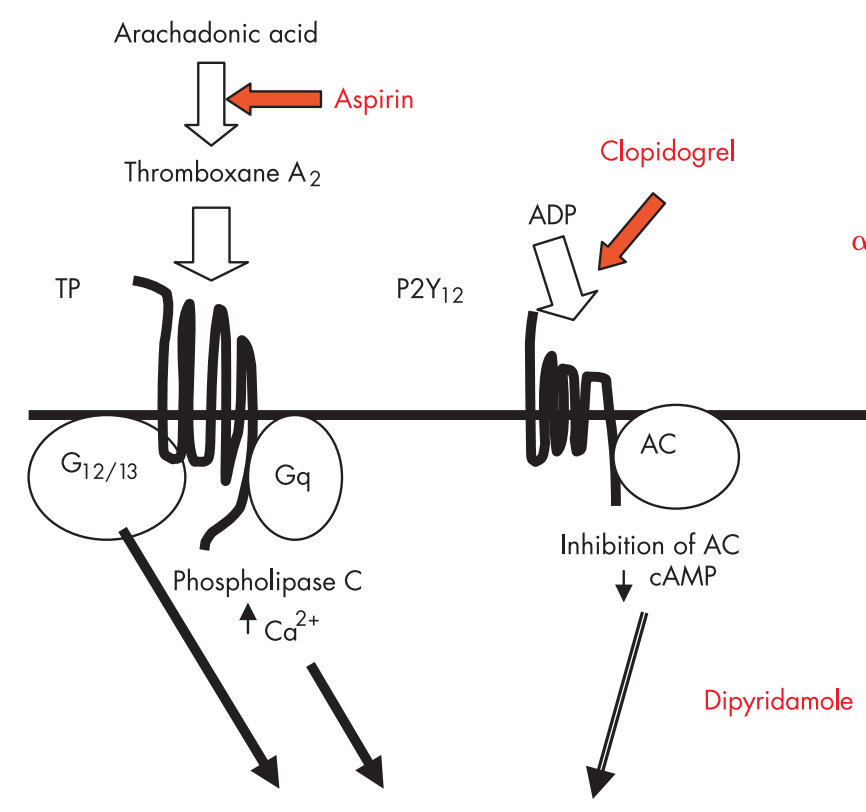

Platelet aggregation
Figure 1 Platelet receptors and their antagonists. The ADP P2Y 12 receptor (a $G$-protein coupled receptor) is linked to adenylate cyclase $(\mathrm{AC})$ via $\mathrm{Gi}$. Upon stimulation the adenylate is inhibited, leading to a fall in CAMP and promotion of platelet aggregation. Clopidogrel irreversibly binds to the ADP P2Y 12 receptor preventing the inhibition of adenylate cyclase,

therefore maintaining CAMP levels and inhibiting platelet aggregation.

Dipyridamole is a phosphodiesterase inhibitor and prevents the breakdown of cAMP and cGMP. Therefore cAMP and cGMP levels are maintained inhibiting platelet aggregation.

Thromboxane $A_{2}$ is produced from arachidonic acid via cyclo-oxygenase and is released from the platelet to work with the TP receptor. The TP receptor (a G-protein coupled receptor) causes platelet aggregation via both $\mathrm{Gq}$ and $G 12 / 13$. Aspirin irreversibly inhibits cyclo-oxygenase, for the lifetime of the platelet (120 days), preventing thromboxane production. The $\alpha_{\| 1 b} \beta_{3}$ receptor antagonists prevent fibrinogen binding to the $\alpha_{\| l b} \beta_{3}$ receptors and therefore inhibit the "final common pathway of platelet aggregation". action of aspirin depends on the irreversible inhibition of arachidonate cyclo-oxygenase activity in platelets, thereby reducing the extent of thromboxane $\mathrm{A}_{2}$ formation that occurs after activation of phospholipase $\mathrm{A}_{2}$ and release of arachidonic acid. ${ }^{17}$ Thromboxane $\mathrm{A}_{2}$ is a strong platelet agonist that is an effective inducer of platelet granule secretion as well as platelet aggregation. However, phospholipase $\mathrm{A}_{2}$ activation and arachidonic acid release seem to play a relatively minor part in the action of many platelet agonists, with the notable exception of collagen, such that the antiplatelet effects of aspirin are limited and overall aspirin may be considered a relatively weak antiplatelet agent.

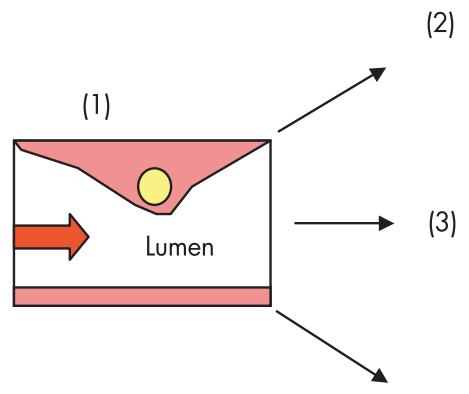

(4)
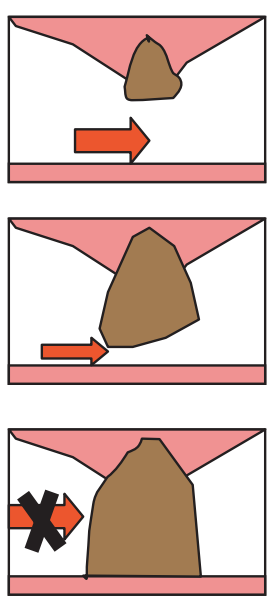

Figure 2 Pathogenesis of thrombosis. In (1) there is a lipid core sealed off by an intact fibrous plaque. The vessel lumen is patent. In (2) there has been a rupture in the plaque covering the lipid core. The exposed prothrombotic lipid-rich core promotes thrombus formation in the plaque. Local platelet activation causes release of platelet agonists, resulting in further platelet activation and vasoconstriction. By (3) the thrombus has extended into the lumen causing partial obstruction. Eventually there is complete luminal obstruction (4).
The Antithrombotic Trialists Collaboration meta-analysis of 135000 patients compared antiplatelet therapy versus control and showed that among "high risk" patients (those with acute or previous vascular disease or other predisposing condition) allocation to antiplatelet therapy reduced the combined outcome of non-fatal myocardial infarction, nonfatal stroke, or vascular death by about one quarter; non-fatal myocardial infarction was reduced by one third, non-fatal stroke by one quarter, and vascular mortality by one sixth. ${ }^{18}$ Available evidence suggests a daily aspirin dose of 75-150 mg for long term prevention of serious vascular events is recommended for high risk patients. In clinical situations where an immediate antithrombotic effect is required (such as acute myocardial infarction, stroke, or unstable angina) a loading dose of $300 \mathrm{mg}$ is recommended. ${ }^{18} 19$

The effect of aspirin on the outcome of patients with unstable angina has been assessed in four double blind placebo controlled trials. ${ }^{20-23}$ The Veterans Administration Cooperative Study randomised 1266 men with unstable angina to aspirin $324 \mathrm{mg}$ daily or placebo. ${ }^{20}$ Death and recurrent non-fatal myocardial infarction at three months were significantly reduced in the aspirin group ( $12.1 \%$ v $5 \%$ in the placebo group, $\mathrm{p}<0.001)$. The other trials showed similar effects of aspirin and the RISC Study showed that aspirin at a dose of $75 \mathrm{mg}$ daily significantly reduced death and myocardial infarction. Other studies have shown that aspirin reduces the incidence of myocardial infarction and sudden cardiac death in patients with stable angina, without influencing the severity or frequency of angina symptoms or the progression of coronary stenosis. ${ }^{24-26}$ On the basis of these results, aspirin is standard treatment for eligible patients with unstable angina.

With the advent of thrombolytic therapy of myocardial infarction, it became clear that treatment with streptokinase was associated with marked platelet activation, as determined by increased thromboxane $\mathrm{A}_{2}$ production. ${ }^{27}$ This issue was addressed by the Second International Study Of Infarct Survival (ISIS-2) which involved 17187 patients with acute myocardial infarction, randomised to one of four arms of 
therapy consisting of placebo, aspirin, streptokinase, or streptokinase plus aspirin. ${ }^{28}$ Aspirin reduced mortality from $13.2 \%$ in the placebo group to $10.7 \%$ (23\% relative risk reduction, $\mathrm{p}<0.00001)$ and streptokinase reduced mortality to $10.4 \%$ (25\% relative risk reduction). However, the combination of aspirin and streptokinase produced the greatest benefit, reducing mortality to $8.0 \%$, an overall relative risk reduction of $42 \%$, thus establishing aspirin and thrombolysis as standard therapy for eligible patients with acute myocardial infarction.

Long term therapy with aspirin is associated with a significant increase in the incidence of gastrointestinal haemorrhage. ${ }^{29}$ No evidence exists that reducing the dose or using modified release formulations reduces the incidence of gastrointestinal haemorrhage. ${ }^{30}$

\section{THIENOPYRIDINES}

This group comprises ticlopidine and clopidogrel, which act by causing irreversible blockade of ADP binding to one of its receptors on the platelet surface, the $\mathrm{P}_{2} \mathrm{Y}_{12}$ receptor. Both drugs are effective orally, with about $80 \%-90 \%$ absorption. They require metabolism by the hepatic cytochrome P450 enzyme system to acquire their antiplatelet activity. ${ }^{31}$

Ticlopidine has been established as an alternative to aspirin in the prevention of recurrent cerebral ischaemia and stroke but its use has been limited in view of its side effects, including thrombotic thrombocytopenic purpura and potentially fatal severe neutropenia. ${ }^{32}$ Due to these side effects and its slow onset of action it has been replaced by clopidogrel, which is felt to be safer and, when a loading dose is employed, faster acting. The CAPRIE trial showed that clopidogrel was slightly more effective than aspirin in reducing ischaemic complications (ischaemic stroke, myocardial infarction, or vascular death) in patients with atherosclerotic disease ${ }^{33}$ but overall, the safety and tolerability of aspirin and clopidogrel were similar. The CAPRIE Study therefore established clopidogrel as an alternative antiplatelet to aspirin for secondary prevention across a wide spectrum of patients with vascular disease.

Ticlopidine in addition to aspirin has been shown to reduce thrombotic complications after intracoronary stent deployment. ${ }^{34}$ In the CLASSICS trial, three regimens were compared in 1020 patients after coronary stent implantation, consisting of aspirin $325 \mathrm{mg}$ once a day plus ticlopidine $250 \mathrm{mg}$ twice a day, aspirin plus clopidogrel $75 \mathrm{mg}$ once a day and aspirin plus clopidogrel $300 \mathrm{mg}$ loading dose followed by $75 \mathrm{mg}$ once a day. ${ }^{35}$ This study confirmed that clopidogrel, with or without the loading dose, is much better tolerated than ticlopidine and showed no significant difference in major adverse cardiac events between the three groups $(0.9 \%$ ticlopidine, $1.5 \%$ clopidogrel $75 \mathrm{mg}$ group, $1.2 \%$ clopidogrel 300/75 mg group).

The CURE (Clopidogrel in Unstable Angina to Prevent Recurrent Events) study investigated the effect of clopidogrel combined with aspirin in the treatment of patients with nonST elevation acute coronary syndromes. ${ }^{36}$ A total of 12562 patients presenting within 24 hours of onset of symptoms were randomly assigned to receive clopidogrel (300 mg immediately followed by $75 \mathrm{mg}$ once daily) or placebo in addition to aspirin for three to 12 months. The primary outcome-a composite of death from cardiovascular causes, non-fatal myocardial infarction or stroke-occurred in $9.3 \%$ of the patients in the clopidogrel group and $11.4 \%$ of the patients in the placebo group (relative risk $0.8 ; \mathrm{p}<0.001$ ). The secondary endpoint, a composite of the primary endpoint and refractory ischaemia, was also reduced (relative risk 0.86, $\mathrm{p}<0.001)$. The benefits of clopidogrel, observed across various subgroups, were apparent as early as the first 24 hours after randomisation, indicating that the oral loading dose was rapidly effective. The addition of clopidogrel to aspirin was, however, associated with an increased risk of major bleeding, particularly gastrointestinal haemorrhage. This, in part, reflects one of the limitations of combining other oral antithrombotic agents with aspirin in view of the propensity of aspirin to cause gastric erosions and ulceration with associated compromise to haemostasis.

The PCI CURE Study was designed to test whether treatment with clopidogrel, in addition to aspirin, before PCI and continued beyond the standard course of four weeks after PCI is superior to placebo in preventing major ischaemic events. ${ }^{37}$ Altogether 2658 patients who were recruited into the CURE Study and underwent PCI in response to refractory ischaemia or adverse events were examined; 1313 were assigned to clopidogrel and 1345 to placebo. A total of 1730 PCI procedures were performed during the initial hospital stay and 928 after discharge. Patients were pre-treated with clopidogrel for a median of 10 days before PCI. After PCI most $(>80 \%)$ patients in both groups received open label thienopyridine for about four weeks, after which the study drug was restarted for a mean of about seven months. Fewer patients in the clopidogrel group had myocardial infarction or refractory ischaemia before PCI.

The number of patients with the primary endpoint of cardiovascular death, myocardial infarction, or urgent revascularisation was significantly lower in the clopidogrel than in the placebo group. Since the vast majority of patients received open label thienopyridine treatment for the four weeks after the procedure, the improvement in the primary endpoint was presumably caused by pre-treatment with clopidogrel prior to PCI. The results implied that in patients with non-ST elevation acute coronary syndrome in which an invasive strategy was planned, clopidogrel started on admission before the procedure and continued long afterwards was beneficial in reducing both early and late complications.

The efficacy of clopidogrel treatment both pre-PCI and subsequently was also recently addressed by the CREDO (Clopidogrel for the Reduction of Events During Observation) Study. ${ }^{38}$ Long term clopidogrel therapy was associated with a relative reduction in the combined risk of death, myocardial infarction, or stroke. Overall no risk reduction in death, myocardial infarction, or target vessel revascularisation from pre-treatment with clopidogrel was observed. From a subgroup analysis, however, it appeared that there was a reduction in the combined endpoint (death, myocardial infarction, or urgent revascularisation) if clopidogrel was administered more than six hours before the procedure.

Numerous trials have been initiated to study the benefits of combining aspirin and clopidogrel for other indications, such as stroke prevention (the MATCH study) or stable ischaemic heart disease (CHARISMA). Clopidogrel therapy only yields partial blockade of the $\mathrm{P}_{2} \mathrm{Y}_{12}$ receptor, ${ }^{39}{ }^{40}$ and there is much interest in the development of more effective strategies of $\mathrm{P}_{2} \mathrm{Y}_{12}$ receptor antagonism in order potentially to enhance the clinical benefits seen with clopidogrel.

\section{DIPYRIDAMOLE}

Dipyridamole inhibits adenosine uptake in erythrocytes and endothelial cells. This increases plasma adenosine levels, which means that there is more available for binding to the adenosine receptor on the platelet. Adenosine activates the release of adenylate cyclase, which converts cyclic adenosine triphosphate (CATP) to cyclic adenosine monophosphate (cAMP). Dipyridamole also blocks the enzyme cyclic guanine monophosphate (cGMP) phosphodiesterase, thereby inhibiting the breakdown of cGMP. Raised levels of cAMP and cGMP within platelets have antiaggregatory effects.

In patients with ischaemic heart disease, dipyridamole in combination with aspirin has not been found to be better 
than aspirin alone. ${ }^{41}$ In patients with cerebrovascular disease however, the European Stroke Prevention Study 2 (ESPS-2) demonstrated that the co-prescription of modified release dipyridamole (400 mg daily) and aspirin (50 mg daily) was more effective in preventing stroke than either drug alone. ${ }^{42}$ A meta-analysis, of 25 trials comparing dipyridamole plus aspirin with aspirin alone, showed that the addition of aspirin was associated with only a non-significant further reduction in serious vascular events. ${ }^{18}$ The current feeling is that there is not yet sufficient evidence to justify adoption of aspirin and dipyridamole as first line treatment for the secondary prevention of stroke.

\section{$\alpha_{1 \mathrm{Ib}} \beta_{3}$ ANTAGONISTS}

The integrin $\alpha_{\mathrm{IIb}} \beta_{3}$ (glycoprotein IIb/IIIa) is a receptor located on the platelet membrane that mediates platelet aggregation. ${ }^{43}$ These receptors recognise an arginine-glycine-aspartic acid (RGD) sequence contained in adhesive molecules such as fibrinogen and von Willebrand factor. When platelets become activated, $\alpha_{\mathrm{IIb}} \beta_{3}$ is converted into a functional receptor, binding these adhesive proteins ${ }^{44}$ and allowing platelets to aggregate and form a haemostatic plug. Therefore, antagonists of $\alpha_{\mathrm{IIb}} \beta_{3}$ block the final common pathway of platelet aggregation. Three classes of $\alpha_{\mathrm{IIb}} \beta_{3}$ inhibitor have been developed: murine-human chimeric antibodies, such as abciximab; synthetic peptide forms, such as eptifibatide; and synthetic non-peptide (peptidomimetic) forms, such as tirofiban. ${ }^{45}$

The antibody abciximab (ReoPro) has a particularly high avidity for $\alpha_{\mathrm{IIb}} \beta_{3}$ and binds to, and exchanges between, platelets for as long as two weeks, although most of the antithrombotic effect disappears within 12-24 hours after termination of intravenous abciximab infusion. On the other hand, synthetic $\alpha_{\mathrm{IIb}} \beta_{3}$ inhibitors inhibit ex vivo platelet aggregation for only a few hours after the end of an intravenous infusion. Eptifibatide (Integrilin) is a synthetic, conformationally constrained, cyclic heptapeptide, fashioned after the integrin antagonist barbourin. Barbourin is a small protein inhibitor of $\alpha_{\mathrm{Irb}} \beta_{3}$ isolated from the venom of the Southeastern pygmy rattlesnake Sistruvus $m$ barbouri. It is a highly competitive inhibitor of $\alpha_{\mathrm{IIb}} \beta_{3}$ with a half life of 90120 minutes and is excreted by the kidneys. The degree of platelet inhibition is related to the drug dose and plasma concentration. ${ }^{45-47}$ Tirofiban (Aggrastat) is the most developed peptidomimetic compound; it is an analogue of tyrosine that is a highly potent antagonist of fibrinogen binding to $\alpha_{\text {IIb }} \beta_{3}$. This also has a short half life of 90-120 minutes and relies on renal clearance. ${ }^{45}$

Drugs from these three groups have been evaluated in the following clinical situations: PCI with and without stenting, medical management of acute coronary syndromes, and acute myocardial infarction both as an adjunct to lytic therapy and for primary PCI. A large and varied group of trials have been carried out (see tables 1-5).

\section{Intravenous $\alpha_{l 1 b} \beta_{3}$ receptor antagonists in $\mathrm{PCl}$ (see table 1)}

The intravenous use of $\alpha_{\mathrm{IIb}} \beta_{3}$ antagonists has been shown to be effective in patients undergoing PCI (EPIC, EPILOG, and CAPTURE) and stenting (EPISTENT). ${ }^{48-51}$ The benefits are additional to those achieved with other antiplatelet agents and are most prominent with abciximab. In the IMPACT II trial negative results were found with eptifibatide in high and low risk patients undergoing PCI. ${ }^{52}$ The results were felt to be due to inadequate platelet inhibition with the dose used, and in ESPRIT (where a higher dose was used) eptifibatide was demonstrated to be highly effective in PCI with stenting. ${ }^{53}$ TARGET was a head to head comparison of tirofiban versus abciximab in patients with acute coronary syndromes undergoing PCI. The findings demonstrated that tirofiban offered less protection from major ischaemic events than did abciximab with no significant differences in the rates of major bleeding complications or transfusion. ${ }^{54}$ However, there is evidence that the levels of platelet inhibition during the first four hours after receiving a bolus of tirofiban were suboptimal in this study in contrast to the predictable and generally optimal effects of abciximab in the first few hours after bolus administration. ${ }^{55}$

There is now compelling evidence for the routine use of $\alpha_{\mathrm{IIb}} \beta_{3}$ antagonists as an adjunct to aspirin and heparin in patients undergoing PCI.

\section{Intravenous $\alpha_{11 b} \beta_{3}$ antagonists in acute coronary syndromes (see table 2)}

The role of $\alpha_{\mathrm{Irb}} \beta_{3}$ antagonists in the treatment of acute coronary syndromes, independent of the use of coronary revascularisation, was tested in PRISM, PRISM-PLUS, PURSUIT, PARAGON, and GUSTO IV-ACS. ${ }^{56-60}$ There was overall benefit in the groups treated with $\alpha_{\mathrm{IIb}} \beta_{3}$ antagonists; however, the results of GUSTO IV-ACS were disappointing and revealed no benefit of abciximab when added to aspirin and heparin. In TACTICS an early invasive strategy was compared to an early conservative strategy, and the primary endpoint was significantly reduced in the early invasive group. ${ }^{61}$

While there is clear benefit for adjunctive treatment with $\alpha_{\mathrm{IIb}} \beta_{3}$ antagonists in patients with acute coronary syndromes before revascularisation, their role in the purely medical management of these patients is less certain, particularly since many physicians are currently using the combination of aspirin, clopidogrel, and low molecular weight heparin for the management of these patients, which is an advance in practice since trials such as PURSUIT and PRISM.

\section{Intravenous $\alpha_{11 b} \beta_{3}$ antagonists for primary PTCA in acute myocardial infarction (see table 3 )}

The use of $\alpha_{\mathrm{IIb}} \beta_{3}$ antagonists has been assessed in primary PTCA for acute myocardial infarction in ADMIRAL, RAPPORT, and CADILLAC. ${ }^{62-64}$ Abciximab was shown to improve the results of primary angioplasty for the treatment of acute myocardial infarction in the ADMIRAL trial. In RAPPORT, abciximab was associated with a significant reduction in early major adverse cardiac events. In the CADILLAC trial, PTCA alone was compared to PTCA plus abciximab therapy, stenting alone, and stenting plus abciximab therapy. There was no long term benefit from abciximab after primary stenting, although abciximab did reduce the rates of subacute thrombosis and recurrent ischaemia leading to repeated revascularisation of the target vessel during the first few weeks after PTCA or stenting.

On the basis of these trials, there is no definite indication for $\alpha_{\text {IIb }} \beta_{3}$ antagonists as an adjunct to primary PTCA as it has been demonstrated to have variable effects.

\section{Intravenous $\alpha_{11 b} \beta_{3}$ antagonists as adjuncts to lytic therapy in acute myocardial infarction (see table 4)} Combining a $\alpha_{\mathrm{IIb}} \beta_{3}$ antagonist with a thrombolytic has been evaluated in the management of acute myocardial infarction. The combination of half dose recombinant tissue-type plasminogen activator (rt-PA) and abciximab used in the TIMI 14 angiographic patency study resulted in some of the highest rates of optimal (TIMI-3) flow seen among trials of pharmacological reperfusion. ${ }^{65}$

The large GUSTO V outcome study compared reteplase with half dose reteplase plus abciximab in 16588 patients. The results were disappointing, with no significant difference in 30 day mortality rates. The reduction in the number of the secondary endpoints in the combination group, including reinfarction and the need for urgent revascularisation was 
Table $1 \alpha_{\| b} \beta_{3}$ Antagonists in percutaneous coronary intervention (PCI)

\begin{tabular}{|c|c|c|c|c|c|c|}
\hline $\begin{array}{l}\text { Trial } \\
\text { (year) }\end{array}$ & Full name & $\begin{array}{l}\text { Agent used } \\
\text { (n) }\end{array}$ & Entry criteria & Primary endpoints & $\begin{array}{l}\text { Primary endpoint } \\
\text { outcome }\end{array}$ & Complications/comments \\
\hline $\begin{array}{l}\text { EPIC } \\
(1994)\end{array}$ & $\begin{array}{l}\text { Evaluation of c7E3 } \\
\text { for Prevention of } \\
\text { Ischaemic } \\
\text { Complications }\end{array}$ & $\begin{array}{l}\text { Abciximab } \\
\text { (2099) }\end{array}$ & $\begin{array}{l}\text { High risk patients } \\
\text { undergoing } \mathrm{PCl}\end{array}$ & $\begin{array}{l}30 \text { day composite } \\
\text { end point: death, } \mathrm{MI} \text {, } \\
C A B G \text { or repeat } P C l\end{array}$ & $\begin{array}{l}12.8 \% \text { in placebo } \\
v 8.3 \% \text { in abciximab } \\
\text { group }(p=0.008)\end{array}$ & $\begin{array}{l}\text { More frequent bleeding and } \\
\text { transfusions in abciximab } \\
\text { treated patients, although } \\
\text { risk of ischaemic } \\
\text { complications less }\end{array}$ \\
\hline $\begin{array}{l}\text { EPILOG } \\
\text { (1997) }\end{array}$ & $\begin{array}{l}\text { Evaluation in PTCA } \\
\text { to Improve Long-term } \\
\text { Outcome with } \\
\text { Abciximab GPIlb/IIla } \\
\text { Blockade }\end{array}$ & $\begin{array}{l}\text { Abciximab } \\
(2792)\end{array}$ & $\begin{array}{l}\text { High and low risk } \\
\text { patients undergoing } \\
\mathrm{PCl}\end{array}$ & $\begin{array}{l}30 \text { day composite } \\
\text { end point: death, } \\
\text { Ml or urgent } \\
\text { revascularisat-ion }\end{array}$ & $\begin{array}{l}5.7 \% \text { in abciximab } \\
\text { group } v 11.7 \% \\
\text { placebo }(p<0.001)\end{array}$ & $\begin{array}{l}\text { No significant differences in } \\
\text { bleeding. Abciximab reduces } \\
\text { ischaemic complications in } \\
\text { patients undergoing PTCA }\end{array}$ \\
\hline $\begin{array}{l}\text { IMPACT II } \\
\text { (1997) }\end{array}$ & $\begin{array}{l}\text { Integrilin to Minimize } \\
\text { Platelet Aggregation } \\
\text { and Coronary } \\
\text { Thrombosis II }\end{array}$ & $\begin{array}{l}\text { Eptifibatide } \\
\text { (4010) }\end{array}$ & $\begin{array}{l}\text { Patients undergoing } \\
\text { elective, urgent, or } \\
\text { emergency PCl }\end{array}$ & $\begin{array}{l}30 \text { day composite } \\
\text { end point: death, } \mathrm{MI} \text {, } \\
\text { unplanned } \mathrm{CABG} \text { or } \\
\text { repeat } \mathrm{PCl} \text { or stent } \\
\text { for abrupt closure }\end{array}$ & $\begin{array}{l}11.4 \% \text { placebo, } \\
9.9 \% \text { in high } \\
(p=0.22) \text { and } \\
9.1 \% \text { low dose } \\
\text { eptifibatide } \\
(p=0.063)\end{array}$ & $\begin{array}{l}\text { No increased bleeding, } \\
\text { however dose of eptifibatide } \\
\text { used felt to be too low }\end{array}$ \\
\hline $\begin{array}{l}\text { CAPTURE } \\
\text { (1997) }\end{array}$ & $\begin{array}{l}\text { C7E3 Antiplatelet } \\
\text { Therapy in Unstable } \\
\text { Refractory Angina }\end{array}$ & $\begin{array}{l}\text { Abciximab } \\
\text { (1265) }\end{array}$ & $\begin{array}{l}\text { Refractory unstable } \\
\text { angina }\end{array}$ & $\begin{array}{l}\text { Death, } \mathrm{Ml} \text {, or urgent } \\
\text { intervention within } \\
30 \text { days }\end{array}$ & $\begin{array}{l}11.3 \% \text { in abciximab } \\
\text { group } v 15.9 \% \\
\text { placebo }(p=0.012)\end{array}$ & $\begin{array}{l}\text { Major bleeding more } \\
\text { common in abciximab } \\
\text { group. } \\
\text { By } 6 \text { months no difference } \\
\text { between groups }\end{array}$ \\
\hline $\begin{array}{l}\text { RESTORE } \\
\text { (1997) }\end{array}$ & $\begin{array}{l}\text { Randomised Efficacy } \\
\text { Study of Tirofiban for } \\
\text { Outcomes and } \\
\text { Restenosis Trial }\end{array}$ & $\begin{array}{l}\text { Tirofiban } \\
\text { (2139) }\end{array}$ & $\begin{array}{l}\text { ACS patients } \\
\text { undergoing balloon } \\
\text { angioplasty or } \\
\text { directional } \\
\text { atherectomy within } \\
72 \text { hours }\end{array}$ & $\begin{array}{l}30 \text { day composite } \\
\text { end point: death, } \mathrm{MI} \text {, } \\
C A B G \text {, or repeat } \\
\text { angioplasty and stent }\end{array}$ & $\begin{array}{l}\text { Non-significant } \\
\text { reduction in primary } \\
\text { endpoint but } \\
\text { significant reduction } \\
\text { at } 48 \text { hours and } \\
7 \text { days }\end{array}$ & $\begin{array}{l}\text { No difference in major } \\
\text { bleeding between groups. } \\
\text { Tirofiban protects against } \\
\text { early cardiac events related } \\
\text { to thrombotic closure }\end{array}$ \\
\hline $\begin{array}{l}\text { EPISTENT } \\
\text { (1998) }\end{array}$ & $\begin{array}{l}\text { Evaluation of Platelet } \\
\text { llb/llla Inhibitor In } \\
\text { Stenting }\end{array}$ & $\begin{array}{l}\text { Abciximab } \\
\text { (2399) }\end{array}$ & $\begin{array}{l}\text { Patients undergoing } \\
\text { elective or urgent } \\
\text { coronary intervention } \\
\text { suitable for balloon } \\
\text { angioplasty or stenting }\end{array}$ & $\begin{array}{l}30 \text { day composite } \\
\text { end point: death, } \mathrm{MI} \text {, } \\
\mathrm{CABG} \text { or repeat } \mathrm{PCl}\end{array}$ & $\begin{array}{l}10.8 \% \text { in stent }+ \\
\text { placebo, } 5.3 \% \text { in } \\
\text { stent }+ \text { abciximab, } \\
6.9 \% \text { PTCA + } \\
\text { abciximab }\end{array}$ & $\begin{array}{l}\text { No difference in bleeding. } \\
\text { Death and } \mathrm{Ml} \text { still reduced at } \\
1 \text { year. For revascularisation } \\
\text { abciximab and stenting offer } \\
\text { long term clinical benefits }\end{array}$ \\
\hline $\begin{array}{l}\text { ERASER } \\
(1999)\end{array}$ & $\begin{array}{l}\text { The Evaluation of } \\
\text { ReoPro and } \\
\text { Stenting to } \\
\text { Eliminate } \\
\text { Restenosis }\end{array}$ & $\begin{array}{l}\text { Abciximab } \\
(225)\end{array}$ & $\begin{array}{l}\text { Elective patients } \\
\text { requiring one } \\
\text { intracoronary stent } \\
\text { implantation }\end{array}$ & $\begin{array}{l}\% \text { In-stent volume } \\
\text { obstruction }\end{array}$ & $\begin{array}{l}\text { No difference in } \\
\text { endpoints between } \\
\text { all groups }\end{array}$ & $\begin{array}{l}\text { Abciximab does not reduce } \\
\text { neointimal proliferation or } \\
\text { restenosis }\end{array}$ \\
\hline $\begin{array}{l}\text { ESPRIT } \\
(2000)\end{array}$ & $\begin{array}{l}\text { Enhanced } \\
\text { Suppression of } \\
\text { the Platelet } \\
\text { Glycoprotein } \\
\text { llb/Illa Receptor } \\
\text { Using Integrilin } \\
\text { Therapy Trial }\end{array}$ & $\begin{array}{l}\text { Eptifibatide } \\
\text { (2064) }\end{array}$ & $\begin{array}{l}\text { Undergoing non- } \\
\text { urgent } \mathrm{PCl} \text { with a } \\
\text { variety of stents }\end{array}$ & $\begin{array}{l}\text { Combined endpoint: } \\
\text { death, MI, urgent } \\
\text { repeat } \\
\text { revascularisation, } \\
\text { and need for bail } \\
\text { out GPIlb/Illa receptor } \\
\text { blockade at } 48 \text { hours }\end{array}$ & $\begin{array}{l}\text { Significant reduction } \\
\text { from } 10.5 \% \text { to } 6.6 \% \\
(p=0.0017)\end{array}$ & $\begin{array}{l}\text { Higher dose of eptifibatide } \\
\text { felt to be responsible for } \\
\text { better outcome compared to } \\
\text { IMPACT II }\end{array}$ \\
\hline $\begin{array}{l}\text { TARGET } \\
\text { (2001) }\end{array}$ & $\begin{array}{l}\text { Do Tirofiban And } \\
\text { ReoPro Give Similar } \\
\text { Outcomes Trial }\end{array}$ & $\begin{array}{l}\text { Abciximab } \\
v \text { tirofiban }\end{array}$ & $\begin{array}{l}\text { Patients (either elective } \\
\text { or urgent) undergoing } \\
\mathrm{PCl} \text { with "intent to } \\
\text { stent". Not acute } \mathrm{MI}\end{array}$ & $\begin{array}{l}\text { Death, } \mathrm{Ml} \text {, or urgent } \\
\text { revascularisation, at } \\
30 \text { days }\end{array}$ & $\begin{array}{l}7.6 \% \text { in tirofiban } \\
\text { group and } 6 \% \text { in } \\
\text { abciximab group } \\
(p=0.037)\end{array}$ & $\begin{array}{l}\text { Abciximab found to be } \\
\text { superior particularly in ACS } \\
\text { patients. No difference in } \\
\text { major bleeding }\end{array}$ \\
\hline
\end{tabular}

counterbalanced by an increase in bleeding complications and no improvement in the survival rates at one year. ${ }^{66}$

More investigation of the use of $\alpha_{\mathrm{IIb}} \beta_{3}$ antagonists with lytic therapy in acute myocardial infarction is required before a definite decision on their role can be made.

\section{Oral $\alpha_{11 b} \beta_{3}$ antagonists (see table 5)}

To date, large trials of oral $\alpha_{\mathrm{IIb}} \beta_{3}$ antagonists (sibrafiban, orbofiban, and xemilofiban), have reported no obvious benefit and there are excess bleeding complications in those assigned these drugs. Both the Orbofiban in Patients with Acute Coronary Syndromes Thrombolysis in Myocardial Infarction 16 trial (OPUS-TIMI 16) and Sibrafiban Versus Aspirin to Yield Maximum Protection from Ischaemic Heart Events Post-Acute Coronary Syndromes 2 (SYMPHONY 2) trial demonstrated statistically significant increased mortality in the treatment groups. ${ }^{6768}$ Why there should be a detrimental effect compared to intravenous $\alpha_{\mathrm{IIb}} \beta_{3}$ antagonists remains unclear. The increase in mortality may relate to a prothrombotic effect, unfavourable pharmacokinetics, or indeed there may be paradoxical platelet activation with oral agents. Understanding why there is apparently an adverse effect from the oral agents may lead to the design of better agents and dosing regimens.

Overall the development and use of $\alpha_{\mathrm{IIb}} \beta_{3}$ antagonists have been crucial in the management of cardiovascular disease. Their benefit when used in conjunction with PCI is undoubted and now is accepted practice. Their use in the management of acute coronary syndromes without mandatory PCI has a lesser effect but has been proven in the majority of trials. Their use must be combined with risk stratification and other antiplatelet agents.

Further development of these agents for the treatment of acute coronary syndromes including acute myocardial infarction is required.

\section{CONCLUSION}

Ischaemic heart disease is the biggest killer in the Western world and therefore any treatment that improves its outcome may save large numbers of lives. In recent years much attention has focused on inhibiting platelet aggregation in 
Table $2 \alpha_{\| \mathrm{lb}} \beta_{3}$ Antagonists in acute coronary syndromes (ACS)

\begin{tabular}{|c|c|c|c|c|c|}
\hline $\begin{array}{l}\text { Trial } \\
\text { (year) }\end{array}$ & Full name & $\begin{array}{l}\text { Agent } \\
\text { used (n) }\end{array}$ & Primary endpoints & $\begin{array}{l}\text { Primary endpoint } \\
\text { outcome }\end{array}$ & Complications/comments \\
\hline $\begin{array}{l}\text { PRISM } \\
\text { (1998) }\end{array}$ & $\begin{array}{l}\text { Platelet Receptor } \\
\text { Inhibition in Ischaemic } \\
\text { Syndrome Management }\end{array}$ & $\begin{array}{l}\text { Tirofiban } \\
\text { (3232) }\end{array}$ & $\begin{array}{l}\text { Death, } \mathrm{Ml} \text { or refractory } \\
\text { ischaemia at } 48 \text { hours }\end{array}$ & $\begin{array}{l}\text { Heparin group } 5.6 \% v \\
\text { tirofiban group } 3.8 \% \\
(p=0.01)\end{array}$ & $\begin{array}{l}\text { Initial benefit lost after infusion } \\
\text { ceased. No difference in } \\
\text { major bleeding }\end{array}$ \\
\hline $\begin{array}{l}\text { PRISM-PLUS } \\
\text { (1998) }\end{array}$ & $\begin{array}{l}\text { Platelet Receptor } \\
\text { Inhibition in Ischaemic } \\
\text { Syndrome Management } \\
\text { in Patients Limited by } \\
\text { Unstable Signs and } \\
\text { Symptoms }\end{array}$ & $\begin{array}{l}\text { Tirofiban } \\
\text { (1915) }\end{array}$ & $\begin{array}{l}\text { Death, MI or refractory } \\
\text { ischaemia at } 7 \text { days }\end{array}$ & $\begin{array}{l}17.9 \% \text { heparin } v \\
12.9 \% \text { tirofiban }+ \\
\text { heparin }(p=0.004) \\
\text { Benefit present at } \\
30 \text { days and } 6 \text { months }\end{array}$ & $\begin{array}{l}\text { Unexpected excess } 7 \text { day mortality } \\
\text { in tirofiban alone }(4.6 \%) v \text { heparin } \\
\text { alone }(1.1 \%) \text {. No differences in } \\
\text { bleeding }\end{array}$ \\
\hline $\begin{array}{l}\text { PURSUIT } \\
\text { (1998) }\end{array}$ & $\begin{array}{l}\text { Platelet Ilb/Illa in } \\
\text { Unstable Angina: } \\
\text { Receptor Suppression } \\
\text { Using Integrilin Therapy }\end{array}$ & $\begin{array}{l}\text { Eptifibatide } \\
\text { (10 948) }\end{array}$ & $\begin{array}{l}\text { Death and non-fatal } \\
\mathrm{Ml} \text { at } 30 \text { days }\end{array}$ & $\begin{array}{l}\text { Eptifibatide } 14.2 \% \\
\text { v placebo } 15.7 \% \\
(p=0.04)\end{array}$ & $\begin{array}{l}\text { Eptifibatide effective in reducing } \\
\text { primary endpoint in patients with } \\
\text { ACS. Increased bleeding in } \\
\text { eptifibatide group }\end{array}$ \\
\hline $\begin{array}{l}\text { PARAGON } \\
\text { (1998) }\end{array}$ & $\begin{array}{l}\text { Platelet Ilb/Illa } \\
\text { Antagonism for the } \\
\text { Reduction of Acute } \\
\text { Coronary Syndrome } \\
\text { Events in the Global } \\
\text { Organization Network }\end{array}$ & $\begin{array}{l}\text { Lamifiban } \\
\text { (2282) }\end{array}$ & $\begin{array}{l}\text { Death and non-fatal } \\
\mathrm{Ml} \text { at } 30 \text { days }\end{array}$ & $\begin{array}{l}\text { Non-significant } \\
\text { difference }\end{array}$ & $\begin{array}{l}\text { However low dose Lamifiban and } \\
\text { heparin yielded similar bleeding } \\
\text { rates as the control group but fewer } \\
\text { ischaemic events at } 6 \text { months }\end{array}$ \\
\hline $\begin{array}{l}\text { TACTICS } \\
\text { (TIMI 18) } \\
(2001)\end{array}$ & $\begin{array}{l}\text { (Thrombolysis in } \\
\text { Myocardial Infarction) } \\
\text { Treat Angina with } \\
\text { Aggrastat and Determine } \\
\text { Cost of Therapy with } \\
\text { Invasive or Conservative } \\
\text { Strategy }\end{array}$ & $\begin{array}{l}\text { Tirofiban } \\
\text { (2200) }\end{array}$ & $\begin{array}{l}\text { Death, non-fatal } \\
\text { myocardial infarction, } \\
\text { and rehospitalisation } \\
\text { for an ACS at six } \\
\text { months }\end{array}$ & $\begin{array}{l}\text { In early invasive } \\
\text { group } 15.9 \% v \\
19.4 \% \text { with } \\
\text { conservative strategy } \\
\text { ( } p=0.025)\end{array}$ & $\begin{array}{l}\text { In intermediate to high risk ACS } \\
\text { patients an early invasive strategy is } \\
\text { preferable. In low risk patients the } \\
\text { outcome of both strategies similar. } \\
\text { Increased bleeding in early invasive } \\
\text { group }\end{array}$ \\
\hline $\begin{array}{l}\text { GUSTO } \\
\text { IV-ACS } \\
(2001)\end{array}$ & $\begin{array}{l}\text { Global Utilisation of } \\
\text { Strategies to Open } \\
\text { Occluded Arteries-IV }\end{array}$ & $\begin{array}{l}\text { Abciximab } \\
(7800)\end{array}$ & $\begin{array}{l}\text { All cause mortality, } \\
\text { composite endpoint of } \\
\text { death, or } \mathrm{Ml} \text {, at } 30 \text { days }\end{array}$ & No risk reduction & $\begin{array}{l}\text { Abciximab is not beneficial as } \\
\text { first line management of ACS }\end{array}$ \\
\hline
\end{tabular}

order to prevent thrombotic occlusion. Currently many agents are available but there is room and evidence for the development of others. Aspirin remains the cornerstone of therapy, although its adverse effects on gastric mucosa contribute to haemostatic compromise. Clopidogrel is beneficial in prevention as well as medical and interventional therapy of acute coronary syndromes. Dipyridamole has not been proven as an effective agent in cardiovascular disease, although it is of benefit in cerebrovascular disease. The $\alpha_{\mathrm{IIb}} \beta_{3}$ antagonists are effective intravenous agents in PCI but their role in the conservative (non-interventional) management of acute coronary syndromes is more controversial.

Platelets not only interact with each other but also leucocytes and it appears increasingly likely that therapy targeted on this interaction could be effective. Antiplatelet therapy is now an accepted weapon in the arsenal of treatment for vascular disease but further research and developments will increase its efficacy.

Table $3 \alpha_{\| b} \beta_{3}$ Antagonists for primary percutaneous transluminal coronary angioplasty (PTCA) in acute myocardial infarction (MI)

\begin{tabular}{|c|c|c|c|c|c|c|}
\hline $\begin{array}{l}\text { Trial } \\
\text { (year) }\end{array}$ & Full name & $\begin{array}{l}\text { Agent } \\
\text { used (n) }\end{array}$ & Entry criteria & Primary endpoints & Primary endpoint outcome & $\begin{array}{l}\text { Complications/ } \\
\text { comments }\end{array}$ \\
\hline $\begin{array}{l}\text { RAPPORT } \\
\text { (1998) }\end{array}$ & $\begin{array}{l}\text { ReoPro for Acute } \\
\text { Myocardial } \\
\text { Infarction and } \\
\text { Primary PTCA } \\
\text { Organization and } \\
\text { Randomised Trial } \\
\text { Low Molecular } \\
\text { Weight Heparin }\end{array}$ & $\begin{array}{l}\text { Abciximab } \\
(483)\end{array}$ & $\begin{array}{l}\text { Within } 12 \text { hours } \\
\text { of the onset of } \\
\text { acute } \mathrm{Ml} \text {, } \\
\text { referred for } \\
\text { angioplasty }\end{array}$ & $\begin{array}{l}\text { All-cause mortality, } \\
\text { non-fatal MI, fatal } \\
\text { MI, urgent TVR at } \\
6 \text { months }\end{array}$ & $\begin{array}{l}\text { No difference in primary } \\
\text { endpoint however } \\
\text { abciximab significantly } \\
\text { reduced death, reinfarction } \\
\text { or TVR at all time points } \\
\text { measured ( } 7 \text { and } 30 \text { days } \\
\text { and } 6 \text { months) }\end{array}$ & $\begin{array}{l}\text { Major bleeding occurred } \\
\text { significantly more in } \\
\text { abciximab group }\end{array}$ \\
\hline $\begin{array}{l}\text { CADILLAC } \\
(2000)\end{array}$ & $\begin{array}{l}\text { Controlled } \\
\text { Abciximab and } \\
\text { Device Investigation } \\
\text { to Lower Late } \\
\text { Angioplasty } \\
\text { Complications }\end{array}$ & $\begin{array}{l}\text { Abciximab } \\
(2082)\end{array}$ & $\begin{array}{l}\text { Symptoms of MI } \\
\text { for }>30 \text { min } \\
\text { within } 12 \text { hours } \\
\text { and lytic eligible } \\
\text { ECG }\end{array}$ & $\begin{array}{l}\text { Composite of death, } \\
\text { reinfarction, disabling } \\
\text { stroke and ischaemia } \\
\text { driven revascularisation } \\
\text { of target vessel }\end{array}$ & $\begin{array}{l}\text { At } 6 \text { months PTCA alone } \\
20 \% \text {, after PTCA plus } \\
\text { abciximab } 16.5 \% \text {, after } \\
\text { stenting } 11.5 \% \text { and after } \\
\text { stenting plus abciximab } \\
10.2 \%\end{array}$ & $\begin{array}{l}\text { No long term benefit of } \\
\text { abciximab after primary } \\
\text { stenting, although } \\
\text { abciximab did reduce } \\
\text { rates of repeated } \\
\text { revascularisation during } \\
\text { first few weeks post-initial } \\
\text { procedure }\end{array}$ \\
\hline $\begin{array}{l}\text { ADMIRAL } \\
(2001)\end{array}$ & $\begin{array}{l}\text { Abciximab Before } \\
\text { Direct Stenting in } \\
\text { Myocardial } \\
\text { Infarction } \\
\text { Regarding Acute } \\
\text { and Long-Term } \\
\text { Follow Up }\end{array}$ & $\begin{array}{l}\text { Abciximab } \\
(300)\end{array}$ & $\begin{array}{l}\text { Patients undergoing } \\
\text { stenting for } \\
\text { symptoms of acute } \\
\text { MI within } 12 \text { hours } \\
\text { of enrolment and } \\
\text { had ST elevation in } \\
2 \text { contiguous leads }\end{array}$ & $\begin{array}{l}\text { Composite of death, } \\
\text { reinfarction or urgent } \\
\text { revascularisation at } \\
30 \text { days }\end{array}$ & $\begin{array}{l}\text { Abciximab group } 6 \% v \\
14.6 \% \text { in placebo group } \\
(p=0.01) \text { and remained } \\
\text { significant through } \\
6 \text { months of follow up } \\
(7.4 \% v 15.9 \%, p=0.02)\end{array}$ & $\begin{array}{l}\text { One major bleeding event } \\
\text { occurred in the abciximab } \\
\text { group compared to none } \\
\text { in placebo group }\end{array}$ \\
\hline
\end{tabular}


Table $4 \alpha_{\| l b} \beta_{3}$ Antagonists as adjuncts to lytic therapy in acute myocardial infarction (MI)

\begin{tabular}{|c|c|c|c|c|c|c|}
\hline $\begin{array}{l}\text { Trial } \\
\text { (year) }\end{array}$ & Full name & $\begin{array}{l}\text { Agent used } \\
\text { (n) }\end{array}$ & Entry criteria & Primary endpoints & Outcome & $\begin{array}{l}\text { Complications/ } \\
\text { comments }\end{array}$ \\
\hline $\begin{array}{l}\text { TIMI } 14 \\
\text { (1999) }\end{array}$ & $\begin{array}{l}\text { Thrombolysis } \\
\text { In Myocardial } \\
\text { Infarction } \\
\text { (TIMI) } 14 \text { Trial }\end{array}$ & $\begin{array}{l}\text { Abciximab } \\
\text { (888) }\end{array}$ & $\begin{array}{l}\text { Chest pain } \\
\text { (within } 12 \text { hours) } \\
\text { and lytic eligible } \\
\text { ST elevation } \\
\text { on ECG }\end{array}$ & $\begin{array}{l}\text { Angiographic achievement } \\
\text { of TIMl grade } 3 \text { flow at } \\
90 \text { min }\end{array}$ & $\begin{array}{l}\text { Abciximab and half dose } \\
\text { alteplase resulted in high } \\
\text { rates of TIMI } 3 \text { flow ( } 77 \% \\
\text { combination } v 62 \% \text { alteplase } \\
\text { alone at } 90 \text { min, } p=0.02 \text { ) }\end{array}$ & $\begin{array}{l}\text { Abciximab increased } \\
\text { TIMI } 3 \text { flow in conjunction } \\
\text { with half dose alteplase, } \\
\text { without an increase in } \\
\text { major bleeding }\end{array}$ \\
\hline $\begin{array}{l}\text { SPEED } \\
(2000)\end{array}$ & $\begin{array}{l}\text { Strategies for } \\
\text { Patency } \\
\text { Enhancement in } \\
\text { the Emergency } \\
\text { Department }\end{array}$ & $\begin{array}{l}\text { Abciximab } \\
\text { (224) }\end{array}$ & $\begin{array}{l}\text { Chest pain and } \\
\text { lytic eligible ST } \\
\text { elevation on ECG }\end{array}$ & $\begin{array}{l}\text { Angiographic achievement } \\
\text { of TIMI grade } 3 \text { flow at } \\
60-90 \text { min }\end{array}$ & $\begin{array}{l}\text { Adding retaplase to } \\
\text { abciximab treatment of } \\
\text { acute } \mathrm{Ml} \text { enhanced the } \\
\text { incidence of early complete } \\
\text { reperfusion }\end{array}$ & $\begin{array}{l}\text { Adding retaplase to } \\
\text { abciximab was } \\
\text { associated with a trend } \\
\text { towards increased } \\
\text { bleeding }\end{array}$ \\
\hline $\begin{array}{l}\text { GUSTO V } \\
(2001)\end{array}$ & $\begin{array}{l}\text { Global } \\
\text { Utilization of } \\
\text { Streptokinase } \\
\text { and Tissue } \\
\text { Plasminogen } \\
\text { Activator for the } \\
\text { Occluded } \\
\text { Coronary Arteries } \\
\text { Trial-Ml }\end{array}$ & $\begin{array}{l}\text { Abciximab } \\
\text { (16 588) }\end{array}$ & $\begin{array}{l}\text { Chest pain } \\
>30 \text { min and } \\
\text { within } 6 \text { hours } \\
\text { and lytic eligible } \\
\text { ECG }\end{array}$ & 30 day mortality & $\begin{array}{l}\text { No significant difference } \\
\text { between reteplase }(5.9 \%) \\
v \text { reteplase and abciximab } \\
(5.6 \%)\end{array}$ & $\begin{array}{l}\text { Reduction in } \\
\text { complications of MI by } \\
\text { combination group was } \\
\text { counterbalanced by } \\
\text { increase in bleeding } \\
\text { complications and no } \\
\text { improvement in } 1 \text { year } \\
\text { survival }\end{array}$ \\
\hline $\begin{array}{l}\text { ASSENT-3 } \\
\text { (2001) }\end{array}$ & $\begin{array}{l}\text { Efficacy and safety } \\
\text { of Tenectaplase in } \\
\text { Combination with } \\
\text { Enoxaparin, } \\
\text { Abciximab or } \\
\text { Unfractionated } \\
\text { Heparin }\end{array}$ & $\begin{array}{l}\text { Abciximab } \\
\text { (6095) }\end{array}$ & $\begin{array}{l}\text { Chest pain within } \\
6 \text { hours and lytic } \\
\text { eligible ECG }\end{array}$ & $\begin{array}{l}\text { Composite of } 30 \text { day } \\
\text { mortality, in-hospital } \\
\text { reinfarction, refractory } \\
\text { ischaemia or one of above } \\
\text { plus in-hospital intracranial } \\
\text { haemorrhage or major bleed }\end{array}$ & $\begin{array}{l}\text { There were significantly } \\
\text { fewer efficacy, and efficacy } \\
\text { plus safety endpoints in the } \\
\text { enoxaparin and abciximab } \\
\text { groups compared to the } \\
\text { unfractionated heparin group }\end{array}$ & $\begin{array}{l}\text { Tenectaplase plus } \\
\text { enoxaparin or abciximab } \\
\text { appeared to reduce the } \\
\text { complications of acute } \\
\text { myocardial infarction }\end{array}$ \\
\hline
\end{tabular}

\section{MULTIPLE CHOICE QUESTIONS (ANSWERS AT END OF REFERENCES)}

In each of the following select the one correct option.

1. Which of the following is not a platelet agonist?
(A) $\mathrm{ADP}$
(B) Collagen
(C) Serotonin
(D) Nitric oxide

2. Aspirin exerts its antiplatelet effect by:
(A) Blocking the final common pathway of platelet activation

(B) Irreversibly inhibiting platelet cyclo-oxygenase

(C) Reversible inhibition of platelet ADP receptors

(D) Inhibiting the conversion of CAMP to 5'AMP

3. Regarding aspirin therapy, which one of the following is true:

(A) Reducing the daily dose from $300 \mathrm{mg}$ to $75 \mathrm{mg}$ has been shown to decrease gastrointestinal complications

Table 5 Oral $\alpha_{\| l b} \beta_{3}$ antagonists

\begin{tabular}{|c|c|c|c|c|c|c|}
\hline Trial (year) & Full name & $\begin{array}{l}\text { Agent } \\
\text { used (n) }\end{array}$ & Entry criteria & Primary endpoints & Primary endpoint outcome & Complications/comments \\
\hline $\begin{array}{l}\text { OPUS-TIMI } \\
16(2000)\end{array}$ & $\begin{array}{l}\text { Orbofiban in } \\
\text { Patients with } \\
\text { Unstable Coronary } \\
\text { Syndromes }\end{array}$ & $\begin{array}{l}\text { Orbofiban } \\
\text { (10 302) }\end{array}$ & $\begin{array}{l}\text { ACS within } 72 \text { hours; } \\
\text { history of CVD, } \\
\text { positive cardiac } \\
\text { markers or ECG } \\
\text { changes }\end{array}$ & $\begin{array}{l}\text { Death, } \mathrm{Ml} \text {, recurrent } \\
\text { ischaemia, urgent } \\
\text { revascularisation, } \\
\text { or stroke }\end{array}$ & $\begin{array}{l}\text { Trial terminated prematurely } \\
\text { because of an unexpected } \\
\text { increase in } 30 \text { day mortality } \\
\text { in the orbofiban group }\end{array}$ & $\begin{array}{l}\text { Orbofiban associated with } \\
\text { increased mortality in } \\
\text { broad population of ACS } \\
\text { patients }\end{array}$ \\
\hline $\begin{array}{l}\text { SYMPHONY } \\
(2000)\end{array}$ & $\begin{array}{l}\text { Sibrafiban versus } \\
\text { Aspirin to Yield } \\
\text { Maximum Protection } \\
\text { from Ischaemic Heart } \\
\text { Events Post- Acute } \\
\text { Coronary } \\
\text { Syndromes }\end{array}$ & $\begin{array}{l}\text { Sibrafiban } \\
\text { (9233) }\end{array}$ & $\begin{array}{l}\text { ACS after } \\
\text { stabilisation }\end{array}$ & $\begin{array}{l}\text { Death, } \mathrm{Ml} \text {, and } \\
\text { severe recurrent } \\
\text { ischaemia at } \\
90 \text { days }\end{array}$ & $\begin{array}{l}\text { No difference between } \\
\text { aspirin group }(9.8 \%) \text {, low } \\
(10.1 \%) \text {, or high dose } \\
\text { sibrafiban }(10.1 \%)\end{array}$ & $\begin{array}{l}\text { Sibrafiban showed no } \\
\text { additional benefit over } \\
\text { aspirin and was associated } \\
\text { with increased major } \\
\text { bleeding }\end{array}$ \\
\hline $\begin{array}{l}\text { EXCITE } \\
(2000)\end{array}$ & $\begin{array}{l}\text { Evaluation of Oral } \\
\text { Xemilofiban in } \\
\text { Controlling } \\
\text { Thrombotic Events }\end{array}$ & $\begin{array}{l}\text { Xemilo- } \\
\text { fiban } \\
\text { (7232) }\end{array}$ & $\begin{array}{l}\text { Patients with } \\
\text { angio-graphic } \\
\text { evidence of } C A D \\
\text { requiring } P C l\end{array}$ & $\begin{array}{l}\text { Death, } \mathrm{Ml} \text { and } \\
\text { recurrent } \\
\text { revascularisation } \\
\text { at } 30 \text { and } 182 \\
\text { days }\end{array}$ & $\begin{array}{l}\text { No difference between } \\
\text { placebo }(13.5 \%) \text {, low } \\
\text { (13.9\%) or high dose } \\
\text { xemilofiban (12.7\%) at } \\
182 \text { days }\end{array}$ & $\begin{array}{l}\text { Significant increase in } \\
\text { major bleeding in } \\
\text { xemilofiban group }\end{array}$ \\
\hline $\begin{array}{l}\text { BRAVO } \\
(9200)\end{array}$ & $\begin{array}{l}\text { Blockade of the } \\
\text { Ilb/Illa Receptor } \\
\text { to Avoid Vascular } \\
\text { Occlusion }\end{array}$ & $\begin{array}{l}\text { Lotrafiban } \\
\text { (9200) }\end{array}$ & $\begin{array}{l}\text { Recent ACS, TIA, } \\
\text { CVA, or PVD }\end{array}$ & $\begin{array}{l}\text { Death, stroke, } \\
\text { recurrent ischaemia, } \\
\text { or revascular-isation } \\
\text { at } 6 / 12-2 \text { years }\end{array}$ & $\begin{array}{l}\text { Stopped at interim } \\
\text { analysis because lotrafibran } \\
\text { had a higher mortality than } \\
\text { placebo }(2.7 \% \vee 2.0 \%)\end{array}$ & $\begin{array}{l}\text { Lotrafiban associated with } \\
\text { higher mortality, more } \\
\text { major bleeding, and a } \\
\text { greater risk of serious } \\
\text { thrombocytopenia }\end{array}$ \\
\hline
\end{tabular}

ACS, acute coronary syndromes; CAD, coronary artery disease; CVA, cerebrovascular accident; CVD, cardiovascular disease; ECG, electrocardiography; MI, myocardial infarction; $n$, number of patients; PCI, percutaneous coronary intervention; PVD, peripheral vascular disease. 


\section{Key points}

Aspirin

- This is the first line treatment for patients with vascular disease without contraindications. A daily dose of 75$150 \mathrm{mg}$ for long term prevention of serious vascular events is recommended for high risk patients.

- Where an immediate antithrombotic effect is required (for example, an acute myocardial infarction or cerebrovascular accident) a loading dose of $300 \mathrm{mg}$ is recommended.

\section{Clopidogrel}

- Clopidogrel has similar safety and tolerability compared with aspirin and is at least as effective in secondary prevention for patients with vascular disease. Clopidogrel is used for long term prevention in patients who cannot tolerate aspirin.

- In patients with non-ST elevation myocardial infarction, clopidogrel in combination with aspirin is more beneficial than aspirin alone. This combination is associated with an increased incidence of serious haemorrhage.

- Clopidogrel is given to patients after stent insertion during $\mathrm{PCl}$. Recent evidence suggests that clopidogrel should be given to all patients pre- $\mathrm{PCl}$ and continued long term afterwards.

\section{GPIlb/Illa receptor antagonists}

- Intravenous GPIlb/Illa receptor antagonists are an effective treatment in patients undergoing $\mathrm{PCl}$. Their role in the medical management of acute coronary syndromes and as an adjunct to lytic therapy in acute myocardial infarction is less certain.

- Trials of oral GPIlb/Illa antagonists have reported no benefit and there are excess bleeding complications in those assigned the drugs.

(B) Aspirin has a very strong antiplatelet effect

(C) Aspirin is given with streptokinase in acute myocardial infarction to prevent pyrexia

(D) The Antithrombotic Trialists Collaboration confirmed the overall benefit of antiplatelet therapy for secondary prevention in high risk patients

4. Regarding the thienopyridines which one of the following is true:
(A) Ticlopidine is as safe as clopidogrel
(B) In the CAPRIE trial clopidogrel was found to be not as effective as aspirin for secondary prevention in patients with atherosclerotic disease
(C) Clopidogrel acts at the platelet $\mathrm{P}_{2} \mathrm{Y}_{12}$ receptor
(D) Clopidogrel does not require hepatic metabolism

5. Regarding the CURE Study which one of the following is true:

(A) There was an increase in major bleeding in the clopidogrel arm of the trial

(B) Patients with acute coronary syndromes were randomly assigned clopidogrel or placebo within four weeks of presentation

\section{Key references}

- Davies MJ. The pathophysiology of acute coronary syndromes. Heart 2000;83:361-6.

- CURE Study Investigators. Effects of clopidogrel in addition to aspirin in patients with acute coronary syndromes without ST-segment elevation. N Engl J Med 2001;345:494-502.

- Antithrombotic Trialists Collaboration. Collaborative meta-analysis of randomised trials of antiplatelet therapy for prevention of death, myocardial infarction, and stroke in high-risk patients. BMJ 2002;324:71-86.

- Coller BS. Anti-GPIlb/Illa Drugs: current strategies and future directions. Thromb Haemost 2001 ;86:427-43.

- Diener H, Cunha L, Forbes C, et al. European Stroke Prevention Study 2. J Neurol Sci 1996;143:1-13.

(C) Patients with ST elevation acute coronary syndromes were recruited

6. Which of the following is true?

(A) Dipyridamole should be used in all patients with ischaemic heart disease

(B) Dipyridamole exerts its antiplatelet effect by blocking cyclo-oxygenase in platelets

(C) Dipyridamole has been shown to have a significant benefit in the secondary prevention of stroke

7. Which one of the following statements about abciximab is true?
(A) Abciximab is a monoclonal antibody
(B) Abciximab is a non-peptide inhibitor
(C) Abciximab's antiplatelet effect ceases immediately when the infusion is stopped
(D) Abciximab is isolated from snake venom

8. Glycoprotein IIb/IIIa receptor antagonists were studied in PCI in which one of the following trials?
(A) GUSTO IV
(B) PURSUIT
(C) PRISM
(D) EPIC

9. Which one of the following was not a trial of oral glycoprotein IIb/IIIa receptor antagonists?
(A) OPUS
(B) SYMPHONY
(C) EXCITE
(D) CADILLAC

10. Which one of the following statements is true?

(A) All trials of glycoprotein IIb/IIIa receptor antagonists as adjuncts to lytic therapy in acute myocardial infarction have shown benefit

(B) Intravenous glycoprotein IIb/IIIa receptor antagonists are effective in patients undergoing PCI

(C) Oral glycoprotein IIb/IIIa receptor antagonists are now accepted treatment for acute coronary syndromes 


\section{Authors' affiliations}

M W H Behan, Division of Cardiovascular Medicine, University Hospital, Nottingham, UK

R F Storey, Cardiovascular Research Group, Northern General Hospital, Sheffield, UK

\section{REFERENCES}

1 Sans S, Kesteloo H, Kromhout D. The burden of cardiovascular diseases on mortality in Europe: Task Force of the European Society of Cardiology on Cardiovascular Mortality and Morbidity Statistics in Europe. Eur Heart $J$ 1997; 18:1231-48.

2 Davies MJ. The pathophysiology of acute coronary syndromes. Heart 2000;83:361-6.

3 Ross R. Atherosclerosis as an inflammatory disease. N Engl J Med 1999;340:115-26.

4 Eisert WG. How to get from antiplatelet to antithrombotic treatment. Am J Ther $2001 ; 8: 443-9$

5 Monroe DM, Hoffman M, Roberts HR. Platelets and thrombin generation. Arterioscler Thromb Vasc Biol 2002;22:1381-9.

6 Heptinstall S. The importance of platelet aggregation in coronary artery disease. British Journal of Cardiology 2000;7(suppl):S27-30.

7 Antman EM, Braunwald E. Acute myocardial infarction. In: Braunwald E, ed. Heart disease: a textbook of cardiovascular medicine. Philadelphia: WB Saunders, 1997: 1184-288.

8 Fuster $\mathrm{V}$. The pathogenesis of coronary artery disease and the acute coronary syndromes. N Engl J Med 1992;326:242-50.

Fernandez-Ortiz A, Badimon J, Falk E, et al. Characterization of the relative thrombogenicity of atherosclerotic plaque components: implications for consequences of plaque rupture. J Am Coll Cardiol 1994:23:1562-9.

10 Falk E, Shah PK, Fuster V. Coronary plaque disruption. Circulation 1995;92:657-71

11 Willerson JT, Cohen LS, Maseri A. Pathophysiology and clinical recognition. In: Willerson JT, Cohen LS, eds. Cardiovascular medicine. New York: Churchill Livingstone, 1995.

12 Clemetson KJ. Platelet activation: signal transduction via membrane receptors. Thromb Haemost 1995;74:149-55.

13 Robbie LA, Booth NA, Croll AM, et al. The roles of alpha 2-antiplasmin and plasminogen activator inhibitor 1 (PAl-1) in the inhibition of clot lysis. Thromb Haemost 1993;70:301-6.

14 Torr-Brown SR, Sobel BE. Attenuation of thrombolysis by release of plasminogen activator type-1 from platelets. Thromb Haemost 1993:72:413-21.

15 Pawar D, Shahani S, Maroli S. Aspirin-the novel antiplatelet drug. Hong Kong Medical Journal 1998;4:415-8

16 Singer R. Acetyl salicylic acid, probable cause for secondary, post tonsillectomy haemorrhage. Preliminary report. Arch Otolaryngol 1945:42:19.

17 Patrano C. Aspirin as an antiplatelet drug. NEngl J Med 1994;330:1287-94.

18 Antithrombotic Trialists Collaboration. Collaborative meta-analysis of randomised trials of antiplatelet therapy for prevention of death, myocardial infarction, and stroke in high-risk patients. BMJ 2002:324:71-86.

19 Buerke M, Pittroff W, Meyer J, et al. Aspirin therapy: optimized platelet inhibition with different loading and maintenance doses. Am Heart $J$ 1995; 130:465-72.

20 Lewis HD, Davis JW, Archibald DG, et al. Protective effects of aspirin against acute myocardial infarction and death in men with unstable angina: results of a Veterans Administration Cooperative Society. N Engl J Med 1983;309:396-403.

21 Cairns JA, Gent M, Singer J, et al. Aspirin, sulphinpyrazone, or both in unstable angina. Results of a Canadian multicenter trial. N Engl J Med 1985;313:1369-75.

22 Theroux $\mathrm{P}$, Ouimet $\mathrm{H}, \mathrm{McC}$ ans J, et al. Aspirin, heparin, or both to treat acute unstable angina. N Engl J Med 1988;319:1105-11.

23 Research Group on Instability in Coronary Artery Disease in Southeast Sweden (RISC). Aspirin (75 mg/day) after an episode of unstable coronary artery disease: long-term effects on the risk of myocardial infarction, occurrence of severe angina and the need for revascularisation. J Am Coll Cardiol 1991:18:1587-93.

24 Manson JE, Grobbee DE, Stamfer MJ, et al. Aspirin in the primary prevention of angina pectoris in a randomised trial of United States physicians. Am J Med 1990;89:772-6.

25 Ridker PM, Manson JE, Gazianio JM, et al. Low-dose aspirin therapy for chronic stable angina: a randomised placebo controlled trial. Ann Intern Med 1991;114:835-9.

26 Juul-Moller S, Edvardsson N, Jahnmatz B, et al. Double-blind trial of aspirin in primary prevention of myocardial infarction in patients in patients with stable chronic angina pectoris. Lancet 1992;340:1421-5.

27 Fitzgerald DJ, Catella F, Roy L, et al. Marked platelet activation in vivo after intravenous streptokinase in patients with acute myocardial infarction. Circulation 1988;77:142-50.

28 ISIS-2 (Second International Study of Infarct Survival) Collaborative Group. Randomised trial of intravenous streptokinase, oral aspirin, both, or neither among 17,187 cases of suspected acute myocardial infarction: ISIS-2. Lancet 1988;ii:349-60

29 Roderick PJ, Wilkes HC, Meade TW. The gastrointestinal toxicity of aspirin: an overview of randomised controlled trials. Br J Clin Pharmaco 1993;35:219-26.
30 Derry S, Kong Loke Y. Risk of gastrointestinal haemorrhage with long-term use of aspirin: met-analysis. BMJ 2000;321:1183-7.

31 Savi P, Nurden P, Levy-Toledano S, et al. Clopidogrel: a review of its mechanism of action. Platelets 1998:9:251-5.

32 Noble S, Goa KL. Ticlopidine. A review of its pharmacology, clinical efficacy and tolerability in the prevention of cerebral ischaemia and stroke. Drugs Aging 1996;8:214-32.

33 CAPRIE Steering Committee. A randomised, blinded, trial of clopidogre versus aspirin in patients at risk of ischaemic events (CAPRIE). Lancet 1996;348:1329-39.

34 Scheming A, Neumann F-J, Kastrati A, et al. A randomized comparison of antiplatelet and anticoagulant therapy after the placement of coronary-artery stents. N Engl J Med 1996:334:1084-9.

35 Bertrand M, Rupprecht HJ, Urban P. Double-blind study of the safety of clopidogrel with and without a loading dose in combination with aspirin compared with ticlopidine in combination with aspirin after coronary stenting the clopidogrel aspirin stent international cooperative study (CLASSICS). Circulation 2000;102:624-9.

36 CURE Study Investigators. Effects of clopidogrel in addition to aspirin in patients with acute coronary syndromes without ST-segment elevation. N Engl J Med 2001;345:494-502

37 Mehta SR, Yusuf S, Peters RJG, et al. Effects of pre-treatment with clopidogrel and aspirin followed by long-term therapy in patients undergoing percutaneous coronary intervention: the PCI-CURE study. Lancet 2001;358:527-33.

38 Steinhubl SR, Berger PB, Tiff Mann III J, et al. Early and sustained dual oral antiplatelet therapy following percutaneous coronary intervention. JAMA 2002;288:2411-20

39 Storey RF, Wilcox RG, Heptinstall S. Comparison of the pharmacodynamic effects of the platelet ADP receptor antagonists clopidogrel and ARC69931 MX in patients with ischaemic heart disease. Platelets 2002;13:407-13

40 Storey RF, Judge HM, Wilcox RG, et al. Inhibition of ADP-induced P-selectin expression and platelet-leukocyte conjugate formation by clopidogrel and the P2Y 12 receptor antagonist AR-C69931MX but not aspirin. Thromb Haemost 2002;88:488-94.

41 Persantin-Aspirin Reinfarction Study (PARIS) Research Group. The persantinaspirin reinfarction study. Circulation 1980;62:V85-8.

42 Diener H, Cunha L, Forbes C, et al. European Stroke Prevention Study 2. J Neurol Sci 1996;143:1-13.

43 Shattil SJ. Function and regulation of the B3 integrins in haemostasis and vascular biology. Thromb Haemost 1995; 74:149-55.

44 Clemetson KJ. Platelet activation: signal transduction via membrane receptors. Thromb Haemost 1995;74:111-16.

45 Coller BS. Anti-GPIlb/Illa drugs: current strategies and future directions. Thromb Haemost 2001;86:427-43.

46 Chew DP, Moliterno DJ. A critical appraisal of platelet glycoprotein IIb/IIla inhibition. J Am Coll Cardiol 2000;36:2028-35.

47 Scarborough RM. Development of eptifibatide. Am Heart 1999:138:1093-104.

48 EPIC Investigators. Use of a monoclonal antibody directed against the platelet glycoprotein Illb/llla receptor in high-risk coronary angioplasty. N Engl I Med 1994;330:956-61.

49 EPILOG Investigators. Platelet glycoprotein Ilb/Illa receptor blockade and low dose heparin during percutaneous coronary revascularisation. N Engl J Med 1997;336:1689-96.

50 CAPTURE Investigators. Randomised placebo-controlled trial of abciximab before and during coronary intervention in refractory unstable angina: the CAPTURE study. Lancet 1997:349:1429-35.

51 Topol EJ, Mark DB, Lincoff AM, et al. For the EPISTENT Investigators. Outcomes at 1 year and economic implications of platelet glycoprotein $\mathrm{llb} / \mathrm{llla}$ blockade in patients undergoing coronary stenting: results from a multicentre randomised trial. Lancet 1999:354:2019-24.

52 IMPACT-II Investigators. Randomised placebo-controlled trial of effect of eptifibatide on complications of percutaneous coronary intervention: IMPACTII. Lancet 1997;349:1422-8.

53 O'Shea JC, Buller CE, Cantor WJ, et al. Long-term efficacy of platelet glycoprotein Ilb/llla integrin blockade with eptifibatide in coronary stent intervention. JAMA 2002;287:618-21

54 Topol EJ, Moliterno DJ, Herrmann HC, et al. TARGET Investigators. Do Tirofiban and ReoPro Give Similar Efficacy Trial. Comparison of two platelet glycoprotein Ilb/Illa inhibitors, tirofiban and abciximab, for the prevention of ischaemic events with percutaneous coronary revascularization. N Engl J Med 2001;344:1888-94.

55 Hobbach H-P, Schuster P. Pharmacodynamic and clinical trials of glycoprotein $\mathrm{llb} / \mathrm{llll}$ inhibitors and potential relationship of results to dosing. Z Kardiol 2003;92:213-8.

56 PRISM Study Investigators. A comparison of aspirin plus tirofiban with aspirin plus heparin for unstable angina. Platelet Receptor Inhibition in Ischaemic Syndrome Management Study Investigators. N Engl J Med 1998;338:1498-505

57 Platelet Receptor in Ischaemic Syndrome Management in Patients Limited by Unstable Signs and Symptoms (PRISM-PLUS) Study Investigators. Inhibition of the platelet glycoprotein $\mathrm{llb} / \mathrm{llla}$ receptor with tirofiban in unstable angina and non-Q-wave myocardial infarction. N Engl J Med 1998:338:1488-97.

58 PURSUIT Trial Investigators. Inhibition of platelet glycoprotein Ilb/Illa with eptifibatide in patients with acute coronary syndromes. N Engl J Med 1998;339:436-43.

59 PARAGON Investigators. International, randomized, controlled trial of lamifiban (a platelet glycoprotein Ilb/llla inhibitor), heparin, or both in unstable angina. Circulation 1998;97:2386-95. 
60 GUSTO IV-ACS Investigators. Effect of glycoprotein Ilb/Illa receptor blocker abciximab on outcome in patients with acute coronary syndromes without early coronary revascularisation: the GUSTO IV-ACS randomised trial. Lancet 2001:357:1915-24.

61 Cannon CP, Weintraub WS, Demopoulos L, et al. The TACTICS- Thrombolysis in Myocardial Infarction. Comparison of early invasive and conservative strategies in patients with unstable coronary syndromes treated with the glycoprotein Ilb/Illa inhibitor tirofiban. N Engl J Med 2001;344:1879-87.

62 Montalescot G, Barragan P, Wittenberg O, et al. For the ADMIRAL Investigators. Platelet glycoprotein Ilb/llla inhibition with coronary stenting for acute myocardial infarction. N Engl J Med 2001;344:1895-903.

63 Brener SJ, Barr LA, Burchenal JE, et al. Randomized, placebo-controlled trial of platelet glycoprotein Ilb/Illa blockade with primary angioplasty for acute myocardial infarction. ReoPro and primary PTCA organization and randomized trial (RAPPORT). Circulation 1998:98:734-41.

64 Stone GW, Grines CL, Cox DA, et al. For the Controlled Abciximab and Device Investigation to Lower Late Angioplasty Complications (CADILLAC) Investigators. Comparison of angioplasty with stenting, with or without abciximab, in acute myocardial infarction. N Engl J Med 2002;346:957-66.
65 Antman EM, Giugliano RP, Gibson CM, et al. Abciximab facilitates the rate and extent of thrombolysis. Results of the thrombolysis in myocardial infarction (TIMI 14) trial. The TIMI 14 Investigators. Circulation 1999;99:2720-32.

66 GUSTO V Investigators. Reperfusion therapy for acute myocardial infarction with fibrinolytic therapy or combination reduced fibrinolytic therapy and platelet glycoprotein Ilb/Illa inhibition: the GUSTO V randomised trial. Lancet 2001;357:1905-14.

67 Cannon CP, McCabe CH, Wilcox RG, et al. Oral glycoprotein Ilb/Illa inhibition with orofiban in patients with unstable coronary syndromes (OPUSTIMI 16). Circulation 2000;102:149-56.

68 SYMPHONY Investigators. Comparison of sibrafiban with aspirin for prevention of cardiovascular events after acute coronary syndromes: a randomised trial. Sibrafiban versus aspirin to yield maximum protection from ischaemic heart events post-acute coronary syndromes. Lancet $2000 \cdot 355 \cdot 337-45$

\section{ANSWERS}

1. D; 2. B; 3. D; 4. C; 5. A; 6. C; 7. A; 8. D; 9. D; 10. B

\section{IMAGES IN MEDICINE}

\section{Painful Horner's syndrome caused by carotid dissection}

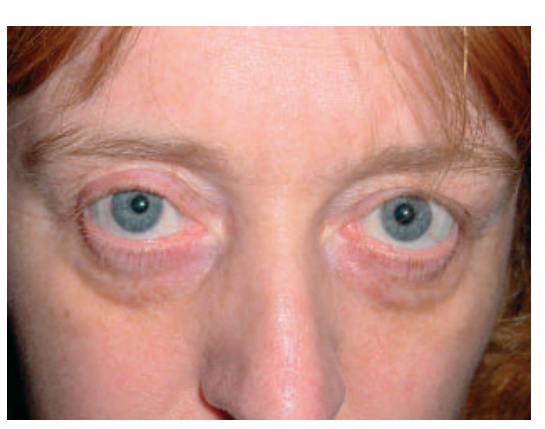

Figure 1 Right Horner's syndrome (published with patient's permission).

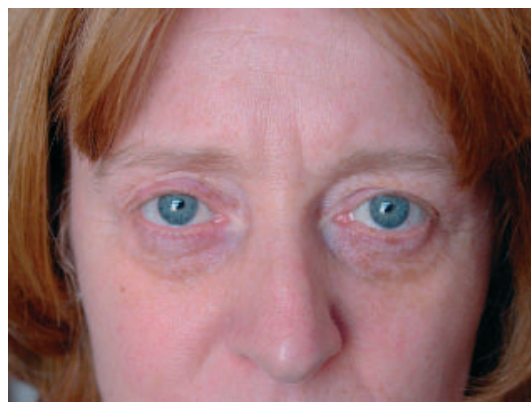

Figure 2 Oculosympathetic miosis (published with patient's permission).
Trisen

his 45 year old woman presented with 10 days of right sided neck and head pain. Figure 1 demonstrates a right Horner's syndrome, fig 2, taken with the curtains open, demonstrates the oculosympathetic miosis that is more easily seen in the dark. Magnetic resonance angiography of her cerebral circulation confirmed a right internal carotid dissection (fig 3); fig 4 demonstrates a false aneurysm and intramural thrombus. A painful Horner's syndrome should be considered due to carotid dissection until proved otherwise. The investigation of choice is magnetic resonance angiography of the cerebral circulation but cross sectional imaging should always include the neck to look for intramural thrombus.

Dissection is believed to cause up to $25 \%$ of strokes in younger patients, the majority of whom will have warning symptoms that potentially allow a window of opportunity to prevent an infarct. The patient was managed with low molecular weight heparin, then warfarin, and has had no ischaemic symptoms after three months of follow up.

D McCorry, J Bamford Department of Neurology, St James University, Hospital, Beckett Street, Leeds LS9 7TF, UK; dougallmccorry@yahoo.com
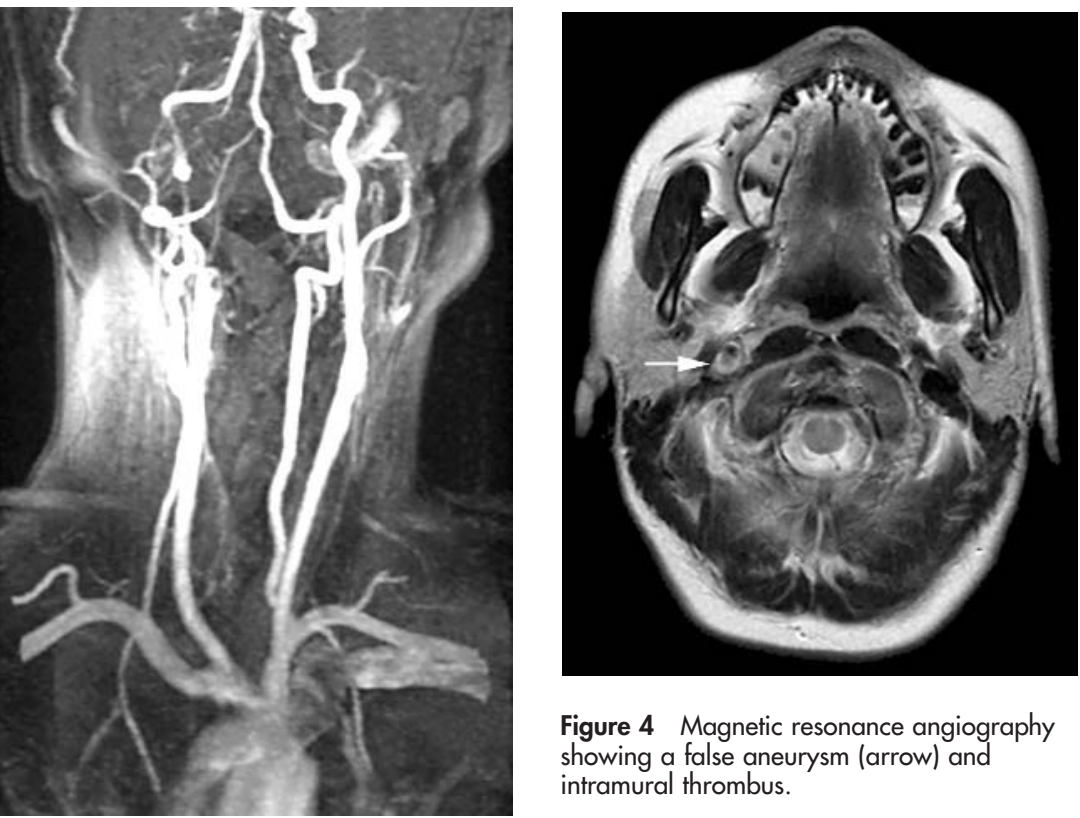

Figure 4 Magnetic resonance angiography showing a false aneurysm (arrow) and intramural thrombus.
Figure 3 Magnetic resonance angiography confirming a right internal carotid dissection. 